\title{
Economic Analysis for HVDC Transmission System in Pakistan
}

\author{
Ali Raza, Armughan Shakeel, Hafiz Tahzeeb ul Hassan, Mohsin Jamil and \\ Syed Omer Gillani \\ School of Mechanical and Manufacturing Engineering (SMME), \\ National University of Sciences and Technology (NUST), \\ Sector H-12, Main Campus, Islamabad, Pakistan \\ aliraza4446@gmail.com,armughanshakeel@gmail.com, \\ tahzibul.hassan@gmail.com,mohsin@smme.nust.edu.pk, \\ omer@smme.nust.edu.pk
}

\begin{abstract}
Electricity is being generated from mega sized power plants based on conventional and non-conventional sources of energy, located in remote areas. Two possible choices are high voltage dc (HVDC) and high voltage ac (HVAC) to transmit bulk power from the remote generation sites to the load centers. This paper aims to present techno-economic comparison of both transmission systems for $4000 \mathrm{MW}$ power plants installed $878 \mathrm{~km}$ far from load centers. Discounted cash flow (DCF) technique is employed for technoeconomic comparison. A soft mechanism is devised in Excel/Microsoft to study the vision in the discrepancy of input factors.
\end{abstract}

Keywords: Economic comparison, HVAC, VSC based HVDC, electrical power transmission system, discounted cash flow analysis

\section{Introduction}

Renewable energy development authority has estimated that the most of transmission lines are over loaded within Pakistan. Energy demands are increasing day by day. Currently, Pakistan is facing energy crises and thus to meet the load demands new proposals for power generation are being suggested like; coal, wind and nuclear plants in southern areas of Pakistan. Coal power plants include Engro Thar Coal $(2 \times 330 \mathrm{MW})$, SSRL Thar Coal $(2 \times 660 \mathrm{MW})$, Port Qasim (1320MW), Thal NOVA (330MW), Oracle (600MW), Lucky Energy (660MW), Siddique Sons Energy (330MW) and Hub power company's Thar coal based plant (300MW) [1]. Wind based plants are being installed in coastal areas (UEP 100MW wind Farm, Jhimpir, Sindh). Nuclear power plants are under construction such as: KANUPP-II (1100MW) and KANUPP-III (1100MW) and proposed to complete till 2022 [2], [3]. Nuclear Power Complex of $1000 \mathrm{MW}$ is proposed in Muzaffargarh with Chinese collaboration [4]. By 2025, thousands of megawatts would be the part of Pakistan's power system. To reinforce the power system, new transmission lines are mandatory. A new transmission network is required in south as most of the power generation projects are planned in the south under the vision of China Pakistan Economic Corridor (CPEC).

Typically, power transmission to the national grid is achieved through high-voltage alternating current (HVAC) [5]. Corona, skin effect and presence of capacitance in the event of no load cause power losses in ac systems, respectively. So, more insulation, big size of conductors and external reactive power supports are required. Thus, HVAC is not suitable to transmit bulk power over long distance. High voltage direct current (HVDC) technology is proposed for bulk power transmission. Reactive power support, black start

Received (June 10, 2017), Review Result (September 30, 2017), Accepted (October 5, 2017) 
capability, small filter sizes, and the ability to change the power direction without altering the polarity of the dc link voltage make voltage source converter (VSC) based HVDC a viable candidate to transmit the power from south to Punjab with reduced investment than HVAC [6], [7].

Location of the proposed bipolar $878 \mathrm{~km}$ VSC-HVDC transmission line from Matiari to Lahore is shown in Figure 1. To fulfill the government objectives of diminishing global warming till 2030, offshore WFs are considered as crucial solution. Europe set a target to produce $120 \mathrm{GW}$ of electrical power from offshore wind energy by 2030. Integration of offshore WFs to mainland grids, to transmit generated power, causes environmental and techno-economic challenges both for transmission system operators (TSO)s and utility[8]-[10]. Thus, HVDC technology either based on VSC or LCC is viable alternative than high voltage alternating current (HVAC) to integrate offshore WFs to onshore grids. Possible choices for power transmission are presented in Figure 2. In dc transmission, charging current on transmission distance with reduced number of conductors and controlled power flow. Transmission planning involves various parameters such as: technical, economic and legal considerations. This paper deals with the economic planning considering the technical and legal aspects. Installation of such a giant transmission network needs as accurate, precise and economic planning as possible.

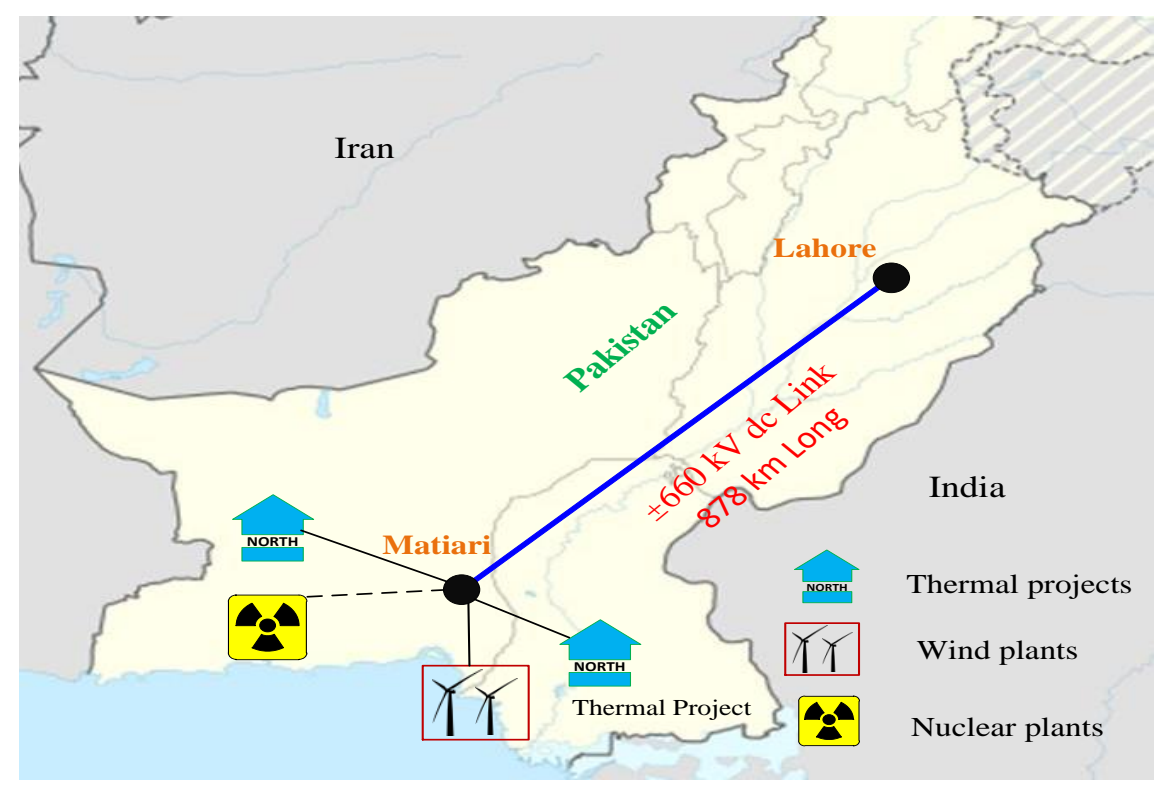

Figure 1. 4000MW Project of South of Pakistan

Appropriate choices regarding technology and line routing is adapted to achieve proper cost optimization. The study conducted is based on the economic factors like; cost comparison, net present value, initial capital cost, annual cost, taxation rate, discounted factor and annuity factor. DCF is proposed for analysis of VSC based HVDC bipolar transmission system [6], [11]. Discounted cash flow technique is a reliable tool to make decisions about capital budgeting of project [12], [13]. 


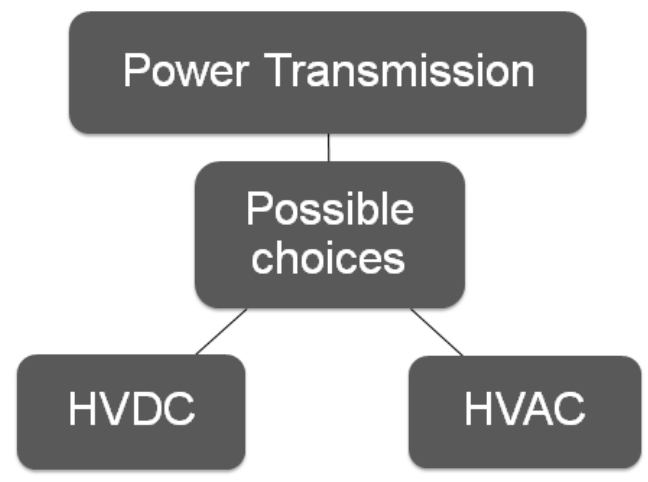

Figure 2. Possible Choices For Electrical Power Transmission

Both the technologies are techno-economically analyzed through DCF which gives the discrepancies in annual costs (AC) and total investment costs (IC). An annual cost consists of losses within transmission system and both preventive and, maintenance costs. But, insurance amount and reliability of system has not been considered in this study. Initial amount (IA) covers the price of grid stations, overhead $(\mathrm{OH})$-lines, switchgear, poles and land. For HVDC technology, the estimated costs of converter station of $4000 \mathrm{MW}$, overhead system for $1000 \mathrm{~km}$ (lines and poles), cost of land and annual maintenance are $800 \mathrm{M} \$, 915 \mathrm{M} \$, 70 \mathrm{M} \$$ and $60 \mathrm{M} \$$, respectively. For $500 \mathrm{kV}$ HVAC transmission systems, the costs of substation (SS), OH lines, static compensators and of land are $282.872 \mathrm{M} \$, 1357.8 \mathrm{M} \$, 141 \mathrm{M} \$$ and $70 \mathrm{M} \$$, respectively, while maintenance cost is considered $90 \mathrm{M} \$[14]$.

This paper is organized as follows; general comparison between HVAC and HVDC is presented in section II. Adopted methodology is described in section III. CSF outcomes are presented in section IV. Finally, conclusions are drawn in section V.

\section{Comparison between HVAC and HVDC}

A typical techno-economic comparison of HVAC and HVDC is depicted in Figure 3, which shows that HVDC is economical than HVAC beyond the knee point [15]. Power transmission standards and conducting medium, atmospheric circumstances and relative cost statistics affects the distance of the break-even point. Figure 4 depicts a comparison of the losses in 1200MW overhead $(\mathrm{OH})$ transmission line using HVDC and HVAC [16]. A vital factor to find in economic comparison of two systems is to determine the better alternative. Subsequent section provides the insight to this question as in Figure 5 for a $4000 \mathrm{MW}$ over $787 \mathrm{~km}$ long $\mathrm{OH}$ transmission line. HVDC system requires low capital cost because of two conductors for distribution and it has ability to transmit large power over long distances with reduced power losses as $3 \%$ per 1000km [17]. HVDC system gives better voltage regulation in the absence of inductance and capacitance than HVAC system [18]. The HVDC grids are employed for [19]:

i. Interconnection of offshore wind power plants with the existing ac networks

ii. Inter-continental transfer of large quantities of power, i.e. an overlay grid

iii. As the main transmission system: opportunity when no or very weak ac transmission system exists, to actually reinforce the transmission system with dc Example: the African power transmission system.

iv. As a distribution grid for power storage

In the above applications, the dc transmission will have following advantages over HVAC: 


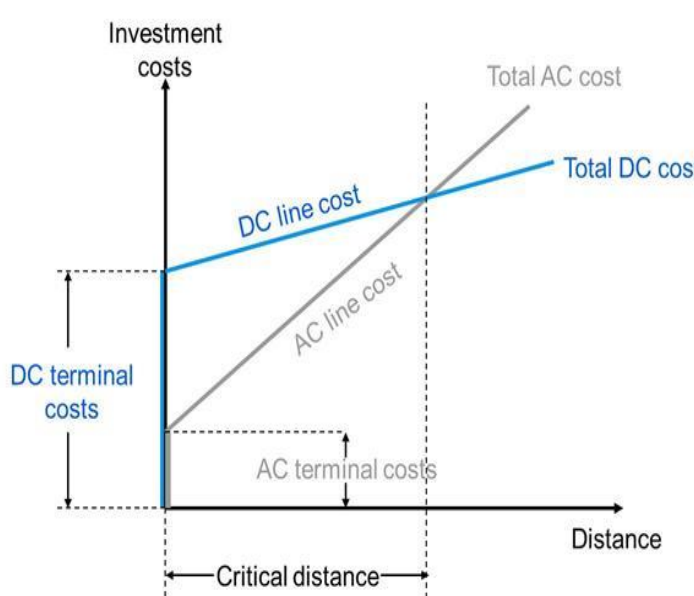

Figure 3. Cost comparison of HVAC and HVDC

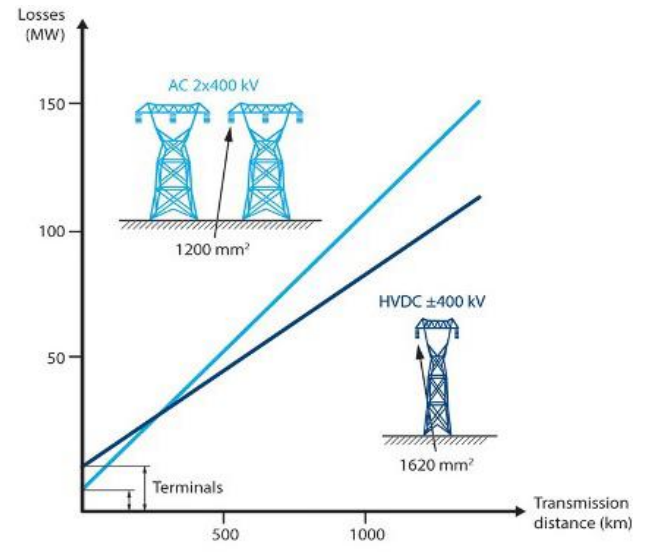

Figure 4. Comparison of the Losses in OHTL

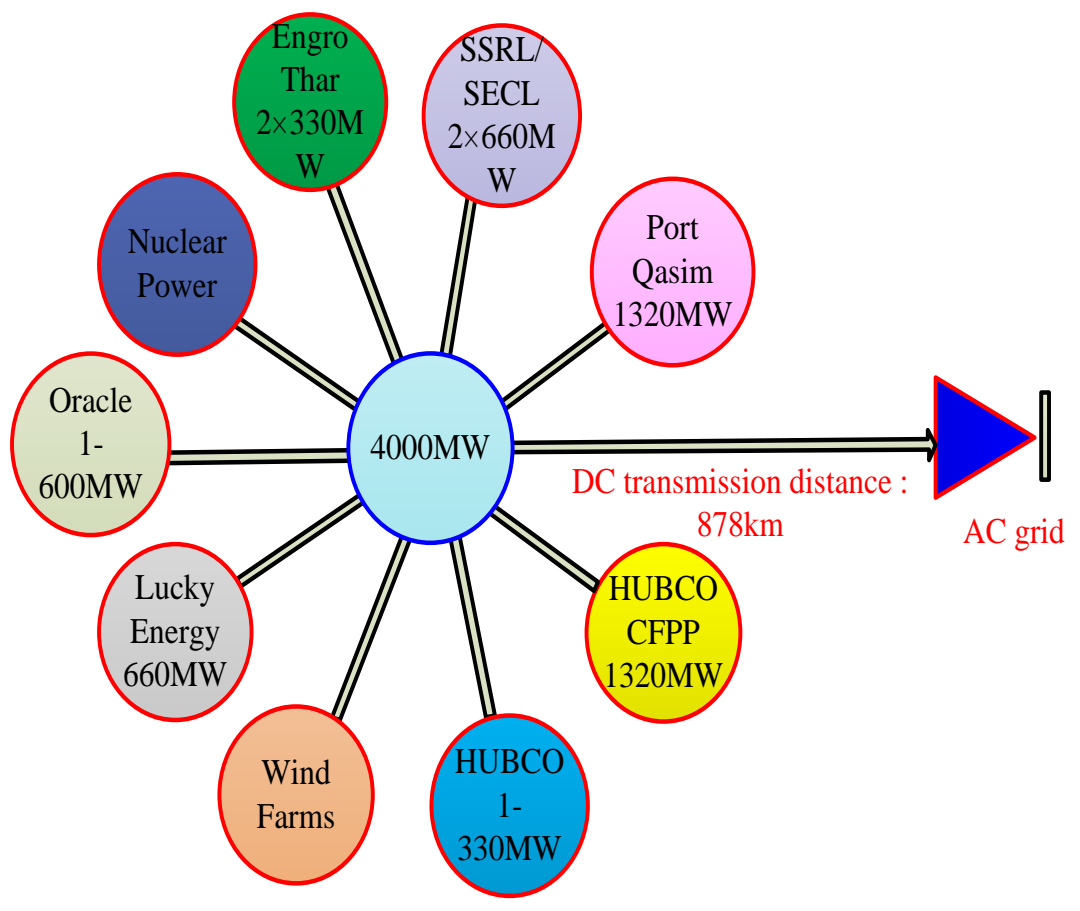

Figure 5. A Scenario for Economic Comparison

i. Number of conductors is reduced for transmission of same quantity of power

ii. Allows power exchange between asynchronous networks

iii. Reduce the long distance losses

iv. More compact overhead line towers, less visual impact

v. Controlled input and output power

vi. The ac fault-ride through capability

Another drawback of HVAC system is the production of charging current as:

$$
I_{C}=\left(\frac{V}{\sqrt{3}}\right)^{2} 2 \pi f C
$$


HVDC technology is of two types: line commutated converters (LCC) and voltage source converters (VSC). LCCs are in need of external source to push off the switches while VSCs do not need, during HVDC applications.

VSC-HVDC offers numerous advantages than LCC-HVDC and some of them are listed in Table I [20]. VSCs also do not require interface transformer and harmonic filters i.e. reduce cost. These are the reason to be ousted from LCC to VSC.

Table I. Comparison between LCC-HVDC and VSC-HVDC

\begin{tabular}{|c|c|c|}
\hline & LCC-HVDC & VSC-HVDC \\
\hline Power Reversal & $\begin{array}{l}\text { Mechanical switches for voltage } \\
\text { reversal as current cannot change } \\
\text { direction }\end{array}$ & $\begin{array}{l}\text { Change of current in the converter. } \\
\text { No need for mechanical switches }\end{array}$ \\
\hline AC disturbances & $\begin{array}{l}\text { Commutation failure: short circuit } \\
\text { of the HVDC Grid for some time }\end{array}$ & $\begin{array}{l}\text { No influence other than some loss of } \\
\text { active power transfer. Fault ride } \\
\text { through capability. }\end{array}$ \\
\hline AC connections & $\begin{array}{l}\text { Limited to medium and high short } \\
\text { circuit capacity networks }\end{array}$ & $\begin{array}{c}\text { Connection to electrically weak AC- } \\
\text { network or even "black" AC } \\
\text { network. }\end{array}$ \\
\hline $\begin{array}{l}\text { AC voltage } \\
\text { support }\end{array}$ & $\begin{array}{l}\text { Always consumes } \sim 50 \% \text { reactive } \\
\text { power (which is compensated by } \\
\text { breaker switched AC filters) }\end{array}$ & Provides reactive power support \\
\hline DC short circuit & $\begin{array}{c}\text { DC Grid breaker needed in overlay } \\
\text { HVDC Grid }\end{array}$ & $\begin{array}{c}\text { DC Grid breaker needed in overlay } \\
\text { HVDC Grid }\end{array}$ \\
\hline $\begin{array}{c}\text { Typical system } \\
\text { losses } \\
\end{array}$ & $0.7 \%$ & $1.1 \%$ \\
\hline $\begin{array}{l}\text { Typical delivery } \\
\text { time }\end{array}$ & 36 months & 24 months \\
\hline
\end{tabular}

Various generalized methods to perform the economic comparisons are shown in Figure 6. Discounted cash flow (DCF) is selected in this paper, where all forthcoming cash flows are calculated and discounted to obtain net present values (NPV) [6].

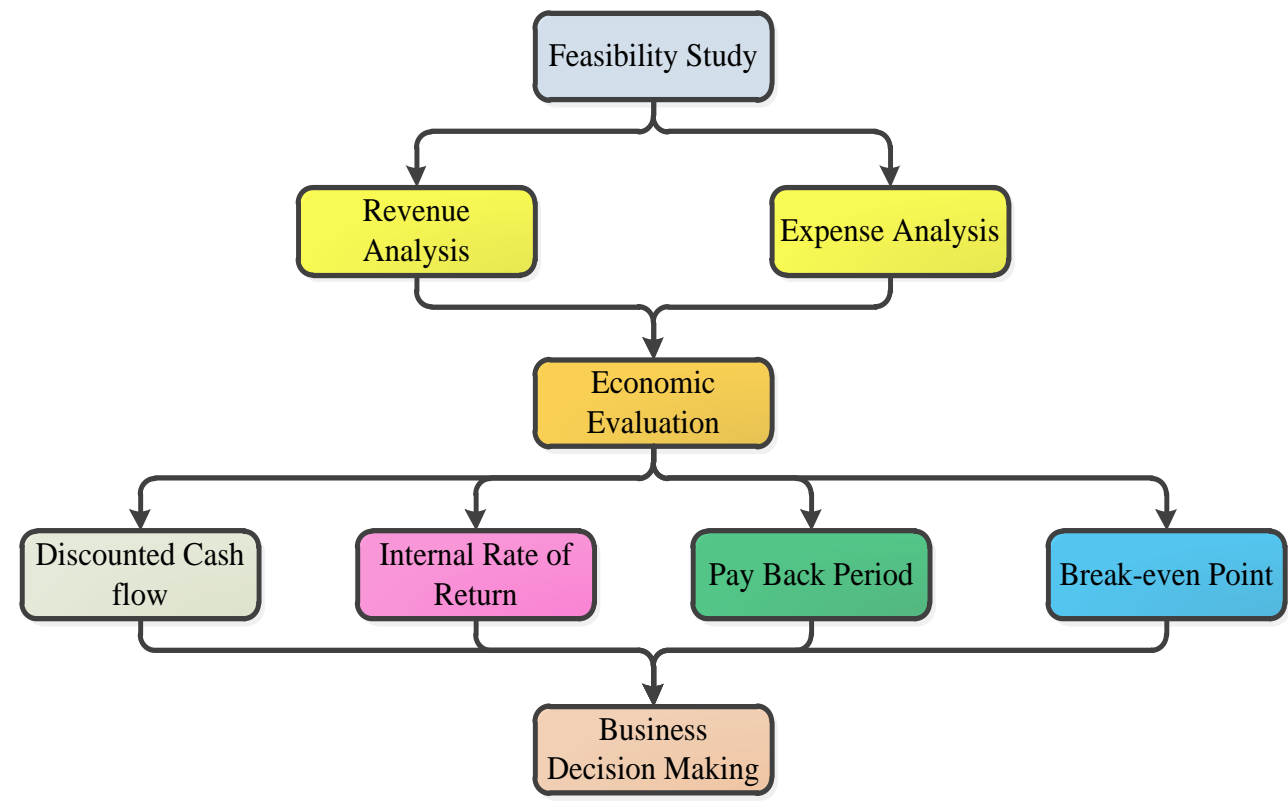

Figure 6. A Typical Procedure for Making Business Decisions 


\section{Methodology}

DCF analysis [11] is employed for comparison between VSC-HVDC and HVAC transmission system. Its outcome is the variance of NPV of two described transmission technologies. Discounted cash flow integrates the discounted annual and original investment costs for each technology. 30 years life spam is considered for the proposed HVDC transmission system. Taxation rate and discounted factors are $17 \%$ and $5.5 \%$, respectively, in Pakistan. Investment cost of both the systems is given in Table II. The employed mathematics is described as:

i. Total invested Amount for HVDC Systems $=$ Cost for Substation + Cost for land (poles and lines) + Cost for overhead Transmission system

ii. Total invested Amount for HVAC Systems $=$ Cost for Substation + Cost for land + Cost for overhead Transmission system (poles and lines) + Cost for Q compensation

iii. Annual Cost $=$ Cost for running losses within system + Cost for maintenance

iv. $\mathrm{NPV}=$ Total Investment + Discounted annual cost

v. $\mathrm{AF}=\left[1-(1+\mathrm{DF})^{\wedge}(-\mathrm{L}) / \mathrm{DF}\right]$

vi. $\mathrm{DAC}=\mathrm{PCF} \times[\mathrm{YC} \times(1-\mathrm{T})-\mathrm{D} \times \mathrm{T}]$

Where

$\begin{array}{ll}\text { AF } & \text { Annuity Factor } \\ \text { DF } & \text { discount factor } \\ \text { L } & \text { Lifetime } \\ \text { DAC } & \text { Discounted annual cost } \\ \text { PCF } & \text { Present cost for AF } \\ \text { YC } & \text { Yearly costs } \\ \text { TR } & \text { Taxation } \\ \text { D } & \text { Depreciation value }\end{array}$

AF can also be found by using annuity standard factor Tables [21].

Table II. Investment Comparison of HVAC and VSC-HVDC Technologies

\begin{tabular}{c|c|c|c}
\hline No. & Components & VSC-HVDC & HVAC \\
\hline 1 & Substation & 800 & 282.872 \\
\hline 2 & Overhead system & 915 & 1357.8 \\
\hline 4 & On shore land use & 70 & 70 \\
\hline 5 & STATCOM & - & 141 \\
\hline & Total & 1785 & 1851.67 \\
\hline
\end{tabular}

\section{Transmission System Investment Cost}

The choice between HVDC and HVAC greatly influences the economy of the project. VSC-HVDC is relatively new technology and offers several technical advantages over HVAC as described in section I.

In this perspective, techno-economic comparison is conducted between HVAC and VSC-HVDC technologies for 4000MW power transmission over $878 \mathrm{~km}$ long $\mathrm{OH}$ lines. The proposed dc system consists of bipolar ground return transmission lines at $660 \mathrm{kV}$ with cross-section of $4 \times 1250 \mathrm{~mm}^{2}$ [1]. Two $660 \mathrm{kV}$ SS are required to install in Matiari and Lahore, respectively. The requirements for the ac transmission system are different. Only one $500 \mathrm{kV}$ grid need to construct as the existing $500 \mathrm{kV}$ Matiari grid station can be used to connect the load centers. Transmission system's cost is presented in Table II for both HVDC and HVAC networks based on their respective components: substations, transmission line conductors, installation and land expenses. Under the same circumstances, the cost of HVAC and VSC-HVDC SS are $800 \mathrm{M} \$$ and $282.8 \mathrm{M} \$$, 
respectively. Cost of VSC-HVDC stations may reduce with the advancements in power electronics. By giving the due attention to the cross-sectional area and distance of lines, the total investment required for the $878 \mathrm{~km} \mathrm{HVAC}$ line is about 1.484 times that of VSCHVDC. Aggregated ac line cost is $1357.8 \mathrm{M} \$$ for $878 \mathrm{~km}$, taking $1.54 \mathrm{M} \$$ per $\mathrm{km} .1 .04 \mathrm{M} \$$ per $\mathrm{km}$ is the installation cost for dc transmission. VSC-HVDC is cheaper than HVAC, with an aggregate distinction of roughly $66.67 \mathrm{M} \$$. VSC-HVDC costs $1785 \mathrm{M} \$$, compared with $1851 \mathrm{M} \$$ of $\mathrm{HVAC}$ to transmit $4000 \mathrm{MW}$ over $878 \mathrm{~km}$.

\section{Annual Cost}

Two components are defined for economic comparison: maintenance (both preventive and corrective) and system losses. The losses in the transmission system are important economic indicator.

The losses in the VSC based HVDC transmission grid originate from the VSCs (e.g., filters, HVDC station transformers and IGBTs,) that are roughly $7.4 \%$ (1.8\% for every station), and line joule losses [6]. Losses in the HVAC system are determined by considering the losses in ac grid station (e.g. transformers and compensation coils), that's $0.5 \%$ of the total power flow [6] and line losses are incorporated. The line losses are due to line conductors. $0.5 \%$ of the total components cost is assessed as the annual maintenance cost [22] and transmission line cost is not included in it. $2.06 \mathrm{M} \$$ and $4.11 \mathrm{M} \$$ are the annual maintenance costs for HVAC and HVDC systems respectively. The cost of HVDC is higher because of the complexity of VSC stations. However, to cope with the charging current produced in HVAC line STATCOM is required. Hence, resulting in increased maintenance cost for HVAC transmission system. Thus, total estimated annual cost for VSC-HVDC is $60 \mathrm{M} \$$ and for HVAC is $90 \mathrm{M} \$$.

\section{Results of DCF Analysis}

Methodology (DCF) presented in section III is used to obtain the comparative results for HVDC and HVAC transmission systems, as in Table III. VSC based HVDC technology is cheaper than HVAC based on the investment cost considering lifetime. Higher annual costs result in higher difference of NPV values for HVAC or VSC-HVDC than the differences in investment costs [6]. This can be seen in Figure 7.

However, continues evolution of power electronics shall result in further reduction in cost of VSC stations, making it more economical option for bulk power transmission.

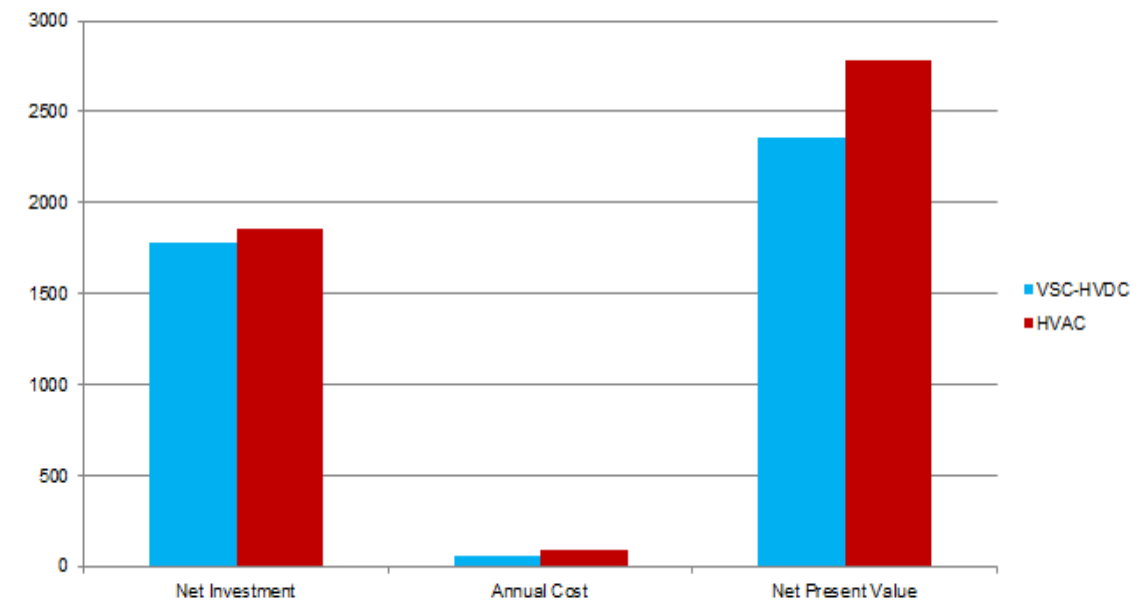

Figure 7. Cost for HVDC and HVAC (M\$) 
Table III. NPV Cost for HVDC and HVAC (M\$)

\begin{tabular}{c|c|c|c}
\hline No. & Components & VSC-HVDC & HVAC \\
\hline 1 & Net Investment & 1785 & 1851.67 \\
\hline 2 & Annual Cost & 60 & 90 \\
\hline 3 & Net Present Value & 2361.77 & 2784.84 \\
\hline
\end{tabular}

\section{Conclusion}

Economic comparison between HVAC and HVDC is presented in this paper for the connection of large coal, nuclear wind based plant in the south of Pakistan to load center, Lahore. VSC-HVDC bipolar transmission system is proposed for 4000MW power transmission over $878 \mathrm{~km}$ long distance using $\mathrm{OH}$ transmission line based on discounted cash flow analysis. VSC-HVDC net present value result is $2361.7 \mathrm{M} \$$, less than HVAC. Thus, VSC-HVDC offers cost effective and efficient transmission network with black start capability than HVAC system.

HVDC got tremendous scope within Pakistan's power system with the inauguration of CPEC to meet the load demands.

\section{References}

[1] Private power and infrastructure board Pakistan, Government of Pakistan: Petition for determination of Terriff for $660 \mathrm{kV}$ HVDC, Available http://www.nepra.org.pk/Tariff/Petitions/2016/Petition\%20HVDC\%20.PDF, (2016).

[2] A. Hashim, "Karachi: Plan to establish 1,000MW Kanupp-II put on hold", Dawn News, Sindh Karachi, Available at: https://www.dawn.com/news/341145/karachi-plan-to-establish-000mw-kanuppii-put-on-hold, (2009).

[3] Z. Nasir, "Nuclear nightmares to avoid", The Nation. Karachi, Sindh: The Nation Media News Group. Accessed on: March (2017).

[4] S. Shah, "Pakistan in Talks to Acquire 3 Nuclear Plants From China", The Wall Street Journal, Jan. 2014. Accessed on: March (2017).

[5] National Transmission and Dispatch Company, Pakistan www.ntdc.com.pk.

[6] D. Hur, "Economic Considerations Underlying the Adoption of HVDC and HVAC for the Connection of an Offshore Wind Farm in Korea" Journal of Electrical Engineering \& Technology, vol. 7, no. 2, (2012).

[7] K. Meah and S. Ula, "Comparative Evaluation of HVDC and HVAC Transmission Systems", Proceedings of IEEE Power Eng. Society General Meeting, Florida, USA, (2007).

[8] L. Xu and L. Yao, "DC voltage control and power dispatch of a multi-terminal HVDC system for integrating large offshore wind farms", IET Renewable Power Generation, vol. 5, no. 3, (2011).

[9] E. Eriksson, P. Halvarsson, D. Wensky and M. Hausler, "System approach on designing an offshore wind power grid connection", Proceedings of 4th International Workshop on Large-Scale Integration of Wind Power and Transmission Networks for Offshore Wind Farms, Sweden, (2003).

[10] S. M. Bolik, "Grid Requirements and Challenges for Wind Turbines", Proceedings of 4th International Workshop on Large-Scale Integration of Wind Power and Transmission Networks for Offshore Wind Farms, Sweden, (2003).

[11] M. Simkovic, "The Evolution of Valuation in Bankruptcy", Proceedings of National Conference of Bankruptcy Judges, USA, (2016).

[12] Discounted Cash Flow-DCH. www.investopedia.com. Accessed on: 9 May (2016).

[13] F. Steiger, "The Validity of Company Valuation Using Discounted Cash Flow Methods", Available at: https://arxiv.org/ftp/arxiv/papers/1003/1003.4881.pdf, (2008).

[14] R. Pletka, J. Khangura, A, Rawlins, E. Waldren and D. Wilson, Capital Costs for Transmission and Substations: Updated Recommendations for WECC Transmission Expansion Planning, Available at:https://www.wecc.biz/Reliability/2014_TEPPC_Transmission_CapCost_Report_B+V.pdf, (2014).

[15] D. Elliott, K. R. W. Bell, S. J. Finney, R. Adapa, C. Brozio, J. Yu and K. Hussain, "A comparison of AC and HVDC options for the connection of offshore wind generation in Great Britain", IEEE Transaction on Power Delivery, vol. 31, no. 2, (2016).

[16] http://new.abb.com/systems/hvdc/why-hvdc/economic-and-environmental-advantage accessed on: April (2017).

[17] T. W. May, Y. M. Yeap and A. Ukil, "Comparative Evaluation of Power Loss in HVAC and HVDC Transmission Systems", Proceedings of IEEE Region 10 Conference (TENCON), Singapore, (2016). 
[18] V. Behravesh and N. Abbaspour, "New Comparison of HVDC and HVAC Transmission system", International Journal of Engineering Innovation \& Research, vol. 1, no. 3, (2012).

[19] C. Barker and P. Christensen, HVDC Grid Feasibility Study: Working Group B4.52. CIGRE, (2013).

[20] A. Raza, X. Dianguo, S. Xunwen and L. Weixing, "Invasion of High Voltage Direct Current till 2014", Proceedings of IEEE International conference on Control Science and System Engineering (CCSSE), (2014), China

$$
\text { annuity value factor. }
$$

Available

at: https://www.homeworkmarket.com/sites/default/files/q2/29/01/table_2_present_value_annuity.jpg.

[22] M. Rashwan, "Evaluation of HVDC Light ${ }^{\circledR}$ as an Alternative for the Vancouver Island transmission Reinforcement (VITR) Project - Appendix Q", Transgrid Solutions, Report C1023, Tech. Report, (2005). 
International Journal of Control and Automation

Vol. 10, No. 11 (2017) 